Article

\title{
Combustion-Related Properties of Poplar, Willow and Black Locust to be used as Fuels in Power Plants
}

\author{
Esperanza Monedero ${ }^{1, *}$ (D), Juan José Hernández ${ }^{2}$ (D) and Rocío Collado ${ }^{2}$ \\ 1 Universidad de Castilla-La Mancha, Instituto de Investigación en Energías Renovables, \\ 02006 Albacete, Spain \\ 2 Escuela Técnica Superior de Ingenieros Industriales, Universidad de Castilla-La Mancha, 13071 Ciudad Real, \\ Spain; juanjose.hernandez@uclm.es (J.J.H.); mrocio.collado@uclm.es (R.C.) \\ * Correspondence: esperanza.monedero@uclm.es; Tel.: +34-9-6759-9200 (ext. 8213); Fax: +34-9-675-5532
}

Received: 12 June 2017; Accepted: 6 July 2017; Published: 14 July 2017

\begin{abstract}
The physical and thermochemical properties of three short rotation forestry crops (poplar, willow and black locust) have been determined and compared in order to evaluate their suitability (energy potential and combustion-related operation problems) to be used in energy devices. The planting density was 6666 in a rotation of four years and the analysis were performed at the end of the first rotation. The three species showed significant differences regarding production, moisture and ash content, heating value and bulk density. The results obtained allow to establish priorities between species according to the expectable combustion behavior, willow being the most appropriate. Results indicate no problems related to $\mathrm{SO}_{x}$ and $\mathrm{NO}_{x}$ emissions. Moreover, the alkali metals determined in the fuel together with the chlorine content suggest no operation problems related with fouling or harmful corrosion.
\end{abstract}

Keywords: forestry energy crops; power plants; Populus; Salix; Robinia

\section{Introduction}

In the current climate change scenario, woody energy crops appear as a very attractive way to produce lignocellulosic biomass which can be locally used in power plants and/or combined heat and power (CHP) systems, thus also promoting the economic and social development of the regions involved [1]. The forestry species with the highest interest in Europe are poplar (Populus spp.) [2], willow (Salix spp.) [3], eucalyptus (Eucalyptus spp.) [4] and, to a lesser extension, black locust (Robinia pseudoacacia) [5]. All of them are a fast-growing tree plantations and therefore, a promising source of biofuel with a large potential to feed the demand of raw materials from the energy sector and other conventional industrial purposes [6]. Moreover, the Salicaceae family provides a valuable source of woody fuel in areas with high water availability such as those located in Northern Europe [7-10].

The performance and pollutant emissions of power/industrial boilers depend on the physical and chemical properties of the biomass used. It is well known that high moisture and ash content in biomass fuels, together with the presence of other elements such as $\mathrm{Cl}, \mathrm{S}$ and $\mathrm{N}$, can cause unstable flames and combustion inefficiencies (deposits, unburnt fuel) as well as emissions (fly ash, $\mathrm{NO}_{x}, \mathrm{HCl}$ and $\mathrm{SO}_{x}$, particles). Operation issues (unscheduled shutdowns and/or more frequent maintenance actions) are also affected by the biomass properties, mainly those related to the ash/deposits removal and $\mathrm{Cl}$ /S-derived corrosion. Moreover, the ash composition determines its melting point, which can be low enough to favor slagging [11]. Furthermore, the alkali metal compounds (containing $\mathrm{K}$ and $\mathrm{Na}$ ) can react with the silica present in the ash producing a sticky, mobile liquid phase, which can lead to blokages of the airways in the furnace [12]. Among physical properties, particle size distribution and bulk density affect not only the burner requirements and possible fuel losses but also the fuel supply needs and thus, the transport and storage systems in terms of space necessities [13]. Therefore, 
the knowledge of the physical and thermo-chemical properties of the fuel is mandatory to predict its combustion behavior and it allows for selecting the most appropriate taken into consideration the whole process (fuel supply, combustion efficiency and performances, pollutant emissions and operation limitations).

Although many studies have been carried out with regard to short rotation forestry crops, the most of them are focused on agricultural aspects [4,6,14-17], thus further information about the combustion properties of these biofuels is needed. Moreover, some studies show that the plant species has more influence on the biomass properties that other factors such as soil conditions, growing region and even the treatment by fertilizer $[18,19]$. Biomass properties may widely vary between species and genotypes of the same specie [20-22]. Regarding the latter comment, a previous work from the authors [21] (focus on ten different poplar genotypes) showed the "AF2" as an appropriate genotype to be used in combustion processes, the effect of the site characteristics (environmental conditions and soil properties) being much less significant than that of the genotype. The lack of knowledge about the expectable combustion behavior of energy crops is even more important for willow and black locust. Although their agronomic characteristics have been widely studied $[3,5,14,17,23,24]$, there is yet a lack of information regarding their physical and thermochemical combustion-related properties.

In this sense, the aim of this work is to evaluate the combustion behavior and the suitability of three short rotation forestry crops for energy use attending to its physical, thermal and chemical properties. A complete thermochemical and physical characterization of the crops, which has been grown under the same environmental, soil, physiographic and planting condition, has been done. The relative significance of the specie on the properties evaluated has been determined through the corresponding statistical analysis.

\section{Materials and Methods}

Three species were used in this study. These were Salix trianda L. $x$ Salix viminalis L. ("SA04"), Robinia pseudacacia L. ("Nyirsegi"), and Populus x euramericana (Dode) Guinier ("AF-2"), usually known (used throughout the document) as willow, black locust and poplar, respectively. In the case of Populus, "AF-2" has been selected from a previous study according to its properties and production yield [21]. Regarding Salix and Robinia, the genotypes selected ("Nyirsegi" and "SA04", respectively) are those whose accommodation to the climate conditions existing at the southern Europe have been previously proved $[14,17,24]$. After the first rotation, trees were harvested as logs and immediately chipped in the field and sent to the laboratory to be physical and thermo-chemically characterized. The biophysical factors of the plantation are shown in Table 1.

Table 1. Biophysical factors of the site.

\begin{tabular}{cc}
\hline Factors and Determination Methods & Location \\
\hline Latitude $\left({ }^{\circ}\right)$ & 41.5996738 \\
Longitude $\left({ }^{\circ}\right)$ & -4.1280864 \\
Altitude $(\mathrm{m}$, asl) & 756 \\
Annual mean temperature $\left({ }^{\circ} \mathrm{C}\right)$ & 12.1 \\
Mean maximum temperature $\left({ }^{\circ} \mathrm{C}\right)$ & 25.4 \\
Mean minimum temperature $\left({ }^{\circ} \mathrm{C}\right)$ & -0.1 \\
Absolute maximum temperature $\left({ }^{\circ} \mathrm{C}\right)$ & 36.7 \\
Absolute minimum temperature $\left({ }^{\circ} \mathrm{C}\right)$ & -7.7 \\
Annual precipitation $(\mathrm{mm})$ & 316 \\
$\mathrm{~K}(\mathrm{pmm})$ by atomic emission & 219 \\
Mg (meq/100 g) by atomic absorption & - \\
Organic Matter $(\%)$ by Walkey-Black & 1.75 \\
Electric conductivity (mS/cm) by 1:2.5 & 0.82 \\
$\mathrm{P}($ pmm $)$ by Olsen & 5.8 \\
\hline
\end{tabular}


Table 1. Cont.

\begin{tabular}{cc}
\hline Factors and Determination Methods & Location \\
\hline pH by 1:2.5 & 7.7 \\
Active lime (\%) & 5.6 \\
Clay (\%) by ISSS & 41.9 \\
Lime (\%) by ISSS & 23.6 \\
Sand (\%) by ISSS & 34.6 \\
\hline
\end{tabular}

Site preparation and plantation was carried out mechanically in spring 2011 using unrooted cuttings for poplar and willow (20-30 cm in length) and bare rooted cuttings for black locust (30-40 cm in length). The density was 6666 trees ha $^{-1}$ (spaced $3 \times 0.5 \mathrm{~m}$ ) and the rotation was four years.

The plantation included four replicates in a completely randomized design. 25 trees per replicate and specie were used to estimate production. The fresh weight of the aboveground biomass (stem and branches) per plant was determined. Yield data (Table 2) was expressed as dry weight after estimating the humidity content of a subsample from each plot, which was oven-dried to constant weight at $100{ }^{\circ} \mathrm{C}$. No fertilization was performed and irrigation was applied according to the site requirements. Surprisingly, the yield of black locust has been much lower than expected. This could be caused by the extremely dry spring, especially during the planting year, which affected strongly this specie. Nevertheless, due to the successful data of black locust yield obtained by others author in dry zones $[17,25-29]$, the potential of this specie has been considered in this work.

Table 2. Biomass production ( $\mathrm{t} \mathrm{ha}{ }^{-1}$ per year of dry matter) by species.

\begin{tabular}{cccc}
\hline Common Name & Species & Genotype & Production \\
\hline Pl & Populus x euroamericana (Dode) Guinier & 'AF2' & 7.15 \\
Willow & Salix trianda L. $x$ Salis viminalis L. & 'SA04' & 7.58 \\
Black Locust & Robinia pseudoacacia L. & 'Nyirsegi' & 0.91 \\
\hline
\end{tabular}

\section{Experimental Procedure}

\section{Biomass Characterization}

The physical (moisture content $\left(M_{m}\right)$, particle size distribution, bulk density $\left.\left(\varrho_{\mathrm{b}}\right)\right)$ and the thermochemical properties (lower and higher heating value $(L H V, H H V)$, ash content $(A)$, volatile matter $(V)$ as well as the carbon $(C)$, hydrogen $(\mathrm{H})$, nitrogen $(\mathrm{N})$, sulfur $(\mathrm{S})$ and chorine $(\mathrm{Cl})$ contents) were measured in the laboratory. In addition, the alkali metal content in biomass $(\mathrm{Na}, \mathrm{K}, \mathrm{Mg}$ and $\mathrm{Ca}$ ) as well as the silica contents were also determined. Representative samples of each woody species were used according to [30]. Additionally, two or three replicates for each analysis were performed. The methods and equipment used for each determination has been previously described in detail by Monedero et al. [21]. Table 3 summarizes the standards methods and the equipment used to calculate the biomass properties.

In order to provide representative information about the effect of the specie, a one-way statistical analysis of variance (ANOVA, confirming whether the assumptions of normality and homogeneity of variance holds by means of Levene test) has been carried out (different letters ( $a, b$ and c) indicating significant differences between fuels for the studied property). The standard model is expressed as shown in Equation (1):

$$
Y i j=\mu+\tau i+\epsilon_{i j}
$$

where $Y_{i j}$ represents the $j$-th observation on the $i$-th species, $\tau i$ represent the $i$-th specie effect, $E_{i j}$ represents the random error existing in the $j$-th observation on the $i$-th specie and $\mu$ is the common effect for the whole experiment. The statistical analysis was carried out by using the Statistical Package 
for Social Sciences (SPSS Version 22 from IBM Corp., Washington, DC, USA). Mean values obtained have been compared with the Duncan test at the 0.05 level.

Table 3. Summary of methods and equipment for the characterization.

\begin{tabular}{ccc}
\hline Property & Analytical Method & Equipment \\
\hline Particle size distribution & EN 15149-1/EN 15149-2 & Mechanical sieve \\
Bulk density $\left(\varrho_{\mathrm{b}}\right)$ & EN 15103 & Calibrate bottle \\
Sample preparation & EN 14780 & Mill \\
Heating value $(\mathrm{LHV}, \mathrm{HHV})$ & UNE 164001 & Calorimeter \\
Moisture content $\left(M_{\mathrm{m}}\right)$ & EN 14774-3/EN 14774-2 & Furnace \\
Ash content $(A)$ & EN 14775 & Muffle furnace \\
Volatile matter $(V)$ & EN 15148 & Muffle furnace \\
Carbon $(C)$ & EN 15104 & Elemental analyzer \\
Hydrogen $(H)$ & EN 15104 & Elemental analyzer \\
Nitrogen $(N)$ & EN 15104 & Elemental analyzer \\
Oxygen $(O)$ & EN 15289 & Elemental analyzer \\
Sulphur $(S)$ & EN 15289 & Ion chromatograph \\
Chlorine $(C l)$ & By difference & - \\
Alkali metals $(\mathrm{Na}, \mathrm{K}, \mathrm{Mg}, \mathrm{P}, \mathrm{Ca}, \mathrm{Si})$ & By difference & Inductive coupled plasma optical \\
& & emission spectrometer \\
\hline
\end{tabular}

\section{Results and Discussion}

\subsection{Physical Properties}

\subsubsection{Moisture Content}

The moisture content of the fuel is an important parameter in determining efficiency. Freshly cut wood has a moisture content of $55-65 \%$ on a wet basis. This decreases slowly for whole logs. The reduction of this energy loss requires adequate preparation and storage of wood fuels [31]. Figure 1 shows the mean moisture content for the three species together with the statistical analyses performed. The ANOVA analysis showed significant differences in moisture content among the species $(p<0.0001$; $F=8024.35$ ). In fact, black locust is the specie with the lowest moisture content after harvesting, thus requiring less energy consumption or shorter natural-air drying period before combustion [32]. The differences obtained in the moisture content after harvesting between poplar and black locust were similar to that found by Manzone [33], while the value determined for willow is similar to that found by Eisenbies et al. [34].

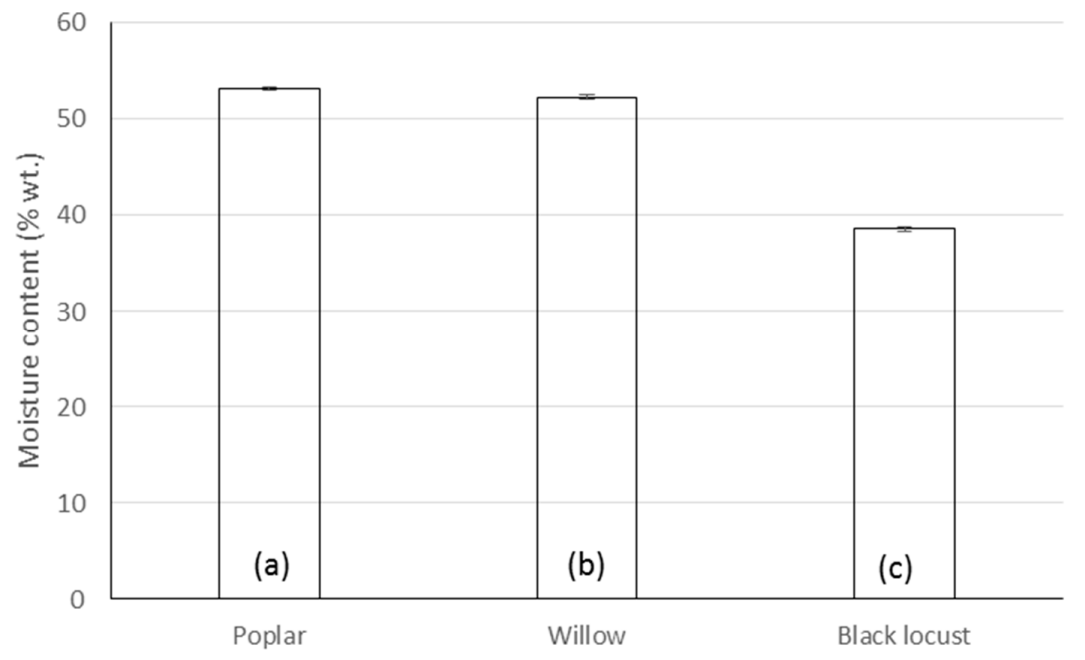

Figure 1. Mean values of moisture content. Means values with by a different letter are significantly different at $p<0.05$. 


\subsubsection{Particle Size Distribution and Bulk Density}

For each specie, results regarding the weight percentage of each fraction in the particle size distribution is shown in Figure 2. All the species are mainly formed by particles between 2.8 and $1.4 \mathrm{~mm}$ (representing $53.05 \mathrm{wt} \%$ for poplar, $46.02 \%$ for willow and $44.79 \%$ for black locust). Comparing the three species, black locust has a greater amount of particles with smallest sizes $(<1 \mathrm{~mm})$, which could originate important fuel losses in the gas strain (mainly when using fluidized bed combustion technologies), affecting both the furnace efficiency as well as the necessities for post-treatment systems such as cyclones or electrostatic precipitators [19].

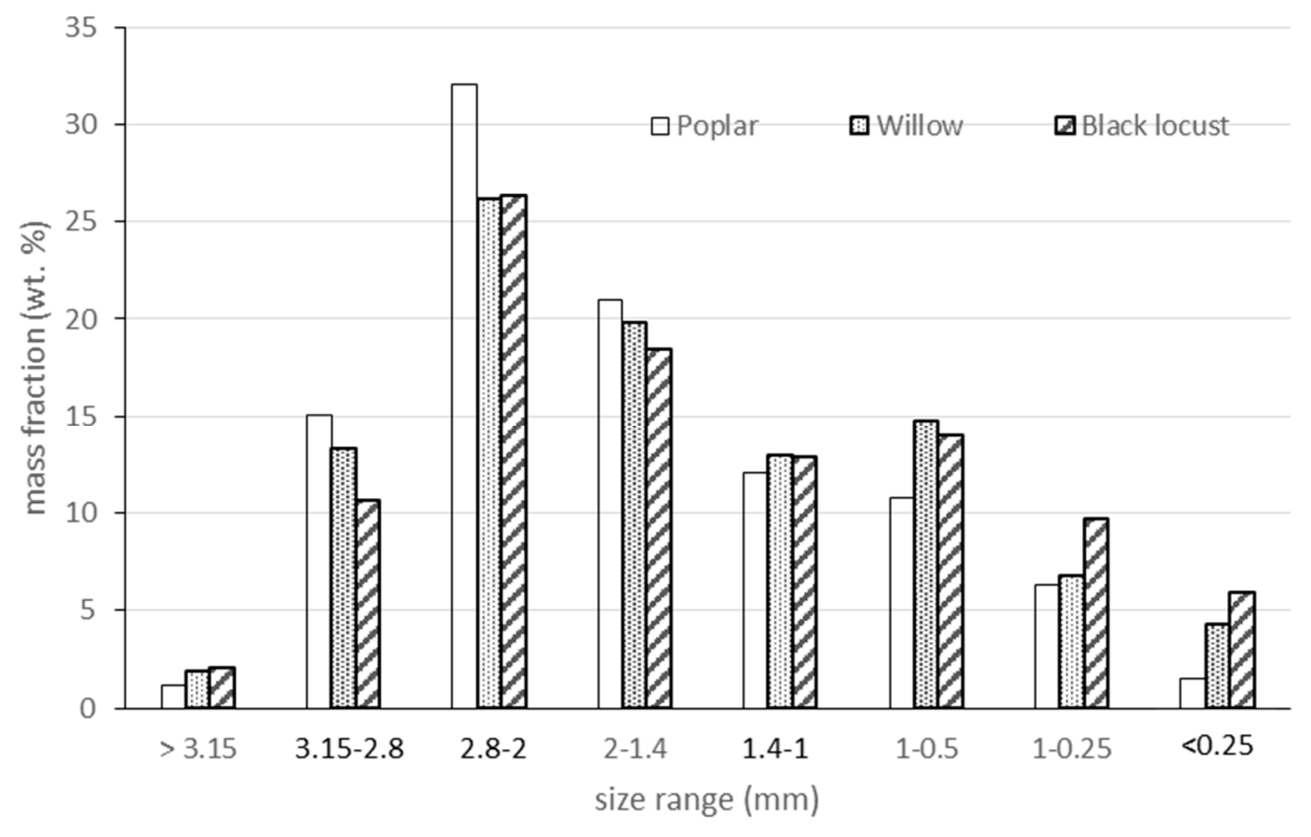

Figure 2. Particle size distribution.

Bulk density is an important characteristic of biomass materials in relation to transport and storage cost [12]. Moreover, together with the lower heating value, it determines the energy density (and thus the energy production of the power plant). Figure 3 shows the mean bulk density for the three species together with the statistical analyses performed. The ANOVA analysis revealed a significant effect of the specie $(p<0.0001 ; F=84.67)$. Black locust $\left(239.83 \mathrm{~kg} \cdot \mathrm{m}^{-3}\right)$ and willow $\left(214.46 \mathrm{~kg} \cdot \mathrm{m}^{-3}\right)$ showed much higher bulk density than poplar $\left(191.81 \mathrm{~kg} \cdot \mathrm{m}^{-3}\right)$. Differences in bark content of each species could lead to the differences observed, as suggested by Picchio et al. [22]. However, the determination of the bark content has not been performed at the current state and it will be considered in the next rotation. The significant larger mean particle size of the poplar biomass could also cause a lower density which is not compensated by its higher moisture content (mainly when compared with black locust). Regarding storage aspects, and assuming a 10 MWe power plant operating $7600 \mathrm{~h} \cdot \mathrm{year}^{-1}$ and an overall efficiency of around 35\%, the required storage volume for black locust would be around $100 \mathrm{~m}^{3}$ smaller than that of poplar. 


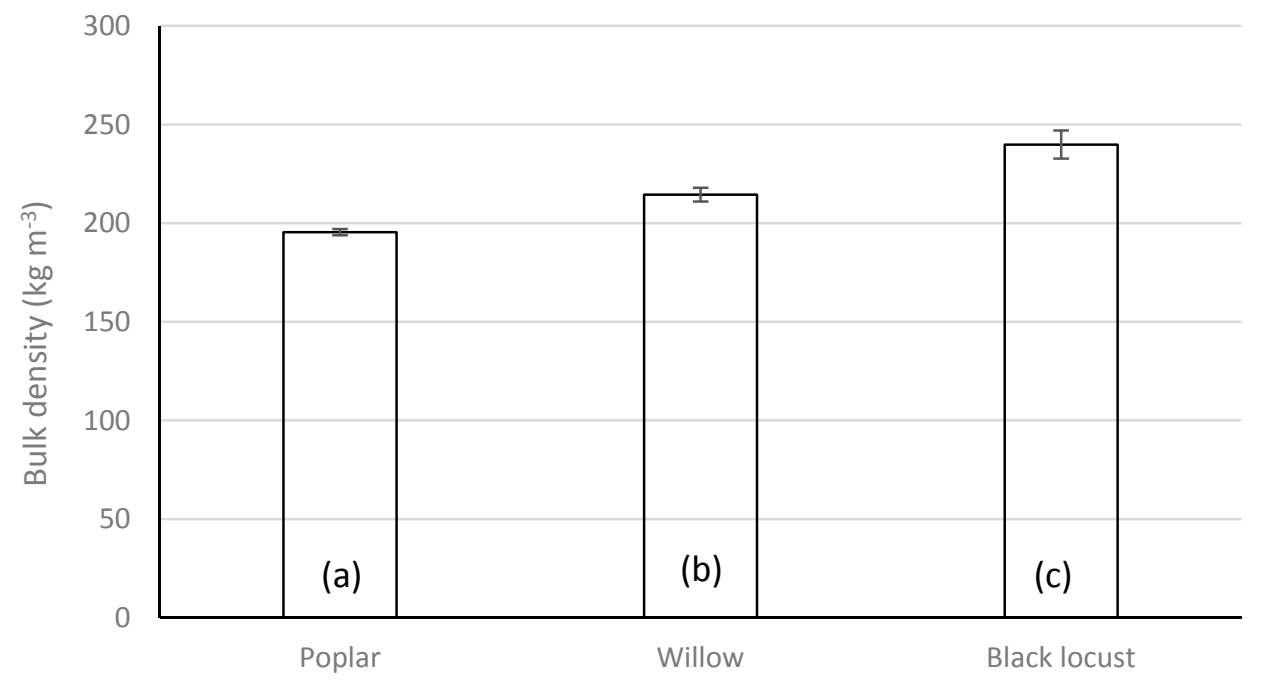

Figure 3. Means values of bulk density $\left(\mathrm{kg} \cdot \mathrm{m}^{-3}\right)$. Mean values with a different letter are significantly different at $p<0.05$.

\subsection{Thermochemical Properties}

\subsubsection{Proximate Analyses and Ash Composition}

The volatile matter of biomass (which is much higher than that of solid fossil fuels) significantly affects the combustion behavior since most of the process is governed by homogeneous reactions [12]. Normally, a high volatile content is desirable because these compounds accelerate the oxidation process improving the efficiency [33]. Unlike its lower fixed carbon content limits the energy supply.

Table 4 shows proximate and ultimate analyses of the three species with the statistical analyses performed. The ANOVA analysis shows a significant effect of the specie $(p<0.0001 ; F=73.513)$ in the volatile matter content, willow showing a slightly higher volatile amount. The values obtained are consistent with those reported by other authors for poplar [35,36], willow [37,38] and black locust [35], although the small relative differences determined do not allow for highlighting a specific crop.

The ash content in the biomass also plays an important role in the combustions process, affecting the combustion technology used. Usually, high ash contents are problematics in combustin devices because ash can cause slag or deposits, and even corrosion troubles wich could reduce the plant throughput, increasing the operating cost [12]. Moreover, high ash content also rises the transportation and storage costs $[17,21]$.

The ANOVA analysis reveals a significant specie effect $(p<0.0001 ; F=754.420)$. These values are similar to those reported by Carmona et al. [16] for poplar, Tharakan et al. [24] and Oberbenguer et al. [39] for willow and Chirone et al. [35] for black locust. In general, the ash content of poplar is slightly higher than that of softwood biomass [40]. Willow had the lowest ash content $(1.88 \mathrm{wt} \%)$, followed by poplar ( $3 \mathrm{wt} \%$ ) and black locust (3.33 wt \%). The values obtained impose no limitations in terms of feedstock for combustion. However, in order to predict the fouling tendency of the biomass when is combusted, the determination of the alkali metal content in the three species has been performed.

It is commonly accepted that the concentration and behavior of elements such as $\mathrm{Ca}, \mathrm{Cl}, \mathrm{K}, \mathrm{Na}, \mathrm{P}, \mathrm{S}$, $\mathrm{Si}$ and some heavy metals are mostly responsible for many technological and environmental problems during biomass processing [41]. Those elements also condition a possible use of the ash, such as soil nutrients ( $\mathrm{K}$ and $\mathrm{Mg}$ content) or as melting additive in the building materials industry (K content). Moreover, the reaction of alkali metals with silica can produce a mobile liquid or sticky phase, which can lead to obstruction of airways inside the boiler as well as to deposits formation in the convection heat transfer surfaces [12]. The alkali metal content (Table 5) is similar for the three species, except 
Ca which is much lower for black locust. Regarding to silicon, willow is the specie with the lowest value. To evaluate the fouling potential of the three species, two indexes (which assume no interaction between the ash elements) have been calculated. Index $\mathrm{A}$ is the ratio of the alkali metal oxides to silica $\left(\mathrm{K}_{2} \mathrm{O}+\mathrm{Na}_{2} \mathrm{O} / \mathrm{SiO}_{2}\right)$ [42] while index $\mathrm{B}$ is referred to the high heating value $\left(\mathrm{K}_{2} \mathrm{O}+\mathrm{Na}_{2} \mathrm{O} x \%\right.$ ash/HHV] [43]. Table 5 shows the fouling indexes calculated with the result of the Duncan test and the range of values for those indexes considering possible fouling problems [38]. The ANOVA analysis revealed a significant effect in indexes A and B $(p<0.0001 ; F=84.00,48.21$, respectively). Additionally, the values shown in Table 5 are indicative of unlikely fouling for all samples. It should be noted that willow, which is significantly different from the other species $(p<0.05)$, is the most suitable for use in combustion processes when fouling phenomena have to be avoided. According to these results, the slightly higher volatile and lower ash content as well as the lower fouling tendency of willow seems to indicate that this species is the most suitable to be used in combustion power plants.

\subsubsection{Ultimate Analyses}

Elemental analysis of a fuel, gives as carbon, hydrogen, nitrogen, chlorine and sulfur content, is termed the ultimate analysis. Table 4 shows the ultimate analysis for the species studied.

According to [35], coniferous and deciduous wood has the lowest $\mathrm{N}$ content. Higher concentrations are found in logging residues, bark or short rotation crops as willow or poplar. The nitrogen content value of the three species range between 0.16 and $0.63 \mathrm{wt} \% \mathrm{~d} . \mathrm{b}$. and no significant differences between species $(p>0.05, F=6.93)$ were found. Nevertheless, as nitrogen content in all species is below to $0.6 \mathrm{wt} \%$, no NOx emissions-related problems should be expected when these species are used in combustion sysetms [40].

The chlorine and sulfur content of wood is normally low. Chlorine and sulfur content in concentrations above 0.1 and $0.2 \mathrm{wt} \%$, respectively, are related with corrosive effect of chorine salts, $\mathrm{HCl}$ and $\mathrm{SOx}$ derived from biomass thermochemical processes [40]. The values determinated ranged between $0-0.02 \mathrm{wt} \%$ d.b. and $0.03-0.05 \mathrm{wt} \%$ d.b., respectively and no significant differences in sulphur and chlorine contents between species were found ( $p>0.05, F=2.838,0.945$, respectively). Again, the low values determined seems to indicate that $\mathrm{Cl}$ and $\mathrm{S}$ associate problems are not expected when the species characterized are used in combustion processes.

\subsubsection{Lower Heating Value}

Figure 4 shows the mean LHV for the three species for both dry and wet basis. Values in dry basis are within the range reported in previous studies of poplar, willow and black locust [16,44]. The ANOVA analysis revealed that the effect of the specie $(p<0.0001 ; F=73.28)$ was significant. Willow showed a slightly higher heating value $\left(17.98 \mathrm{MJ} \cdot \mathrm{kg}^{-1} \mathrm{~d} . \mathrm{b}\right.$.) when compared to poplar $\left(17.93 \mathrm{MJ} \cdot \mathrm{kg}^{-1}\right.$ d.b.), black locust (17.55 MJ. $\mathrm{kg}^{-1}$ d.b.). This is probably due to its lower ash content. Similar findings have been reported by other authors [35]. Considering the production yield (Table 2) and the LHV (dry basis), willow appears again as the most appropriate specie to be used in large-scale combustion devices. However, is known that the moisture content reduces the available energy from the biomass since LHV is reduced proportionally to the moisture content. Therefore, considering the moisture content after harvesting (as received in the power plant), black locust would require a shorter drying time if long storage periods have to be avoided (derived from power production and/or space constraints). 
Table 4. Proximate and ultimate analysis (mean values, wt \% dry basis).

\begin{tabular}{|c|c|c|c|c|c|c|c|c|c|c|c|c|c|c|c|c|c|c|c|c|c|}
\hline \multirow{3}{*}{ Species } & \multicolumn{21}{|c|}{ Factors Evaluated } \\
\hline & \multicolumn{3}{|c|}{ Volatile Matter } & \multicolumn{3}{|c|}{ Ash Content } & \multicolumn{3}{|c|}{ Carbon } & \multicolumn{3}{|c|}{ Hydrogen } & \multicolumn{3}{|c|}{ Nitrogen } & \multicolumn{3}{|c|}{ Sulfur } & \multicolumn{3}{|c|}{ Chlorine } \\
\hline & $\mu$ & SD & & $\mu$ & SD & & $\mu$ & SD & & $\mu$ & SD & & $\mu$ & SD & & $\mu$ & SD & & $\mu$ & SD & \\
\hline Poplar & 82.37 & 0.03 & a & 3.00 & 0.01 & $\mathrm{a}$ & 51.81 & 0.01 & a & 6.39 & 0.08 & $\mathrm{a}$ & 0.16 & 0.02 & a & 0.04 & 0.00 & a & 0.01 & 0.00 & a \\
\hline Willow & 83.59 & 0.39 & $\mathrm{~b}$ & 1.88 & 0.05 & $\mathrm{~b}$ & 48.84 & 0.12 & $\mathrm{~b}$ & 6.18 & 0.05 & $\mathrm{~b}$ & 0.46 & 0.02 & $\mathrm{~b}$ & 0.03 & 0.01 & a & 0.00 & 0.00 & $\mathrm{a}$ \\
\hline Black locust & 81.33 & 0.06 & c & 3.33 & 0.07 & c & 51.51 & 0.18 & c & 6.44 & 0.09 & $\mathrm{a}$ & 0.63 & 0.15 & $\mathrm{~b}$ & 0.05 & 0.00 & $\mathrm{a}$ & 0.02 & 0.00 & $\mathrm{a}$ \\
\hline
\end{tabular}

$\mu$ : average data; SD: standard deviation; Means values followed by a different letter are significantly different at $p<0.05$.

Table 5. Alkali metal and silicon content in poplar, willow and black locust (means values, dry basis) and fouling indexes determined and fouling indexes range.

\begin{tabular}{|c|c|c|c|c|c|c|c|c|c|c|c|}
\hline \multirow{3}{*}{ Species } & \multirow{2}{*}{\multicolumn{5}{|c|}{ Alkali Metals (wt \%) }} & \multicolumn{3}{|c|}{ Index A } & \multicolumn{2}{|c|}{ Index B } & \multirow{2}{*}{$\begin{array}{c}\text { FPR } \\
>0.34\end{array}$} \\
\hline & & & & & & FU & FP & FPR & FU & FP & \\
\hline & $C_{3}$ & $\mathrm{Mr}$ & $\mathbf{K}$ & $\mathrm{Si}$ & $\mathrm{Na}_{2}$ & 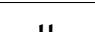 & SD & & 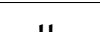 & sn & \\
\hline Poplar & 0.64 & 0.15 & 0.18 & 0.14 & 0.01 & 0.89 & 0.01 & $a$ & 0.13 & 0.01 & $a$ \\
\hline Willow & 0.47 & 0.12 & 0.14 & 0.07 & 0.01 & 0.48 & 0.00 & $\mathrm{~b}$ & 0.05 & 0.00 & $\mathrm{~b}$ \\
\hline Black locust & 0.00 & 0.11 & 0.23 & 0.12 & 0.01 & 0.85 & 0.00 & a & 0.15 & 0.00 & c \\
\hline
\end{tabular}

Means values followed by a different letter are significantly different at $p<0.05$. FU: fouling unlikely, FP: fouling possible, FPR: fouling probable. 


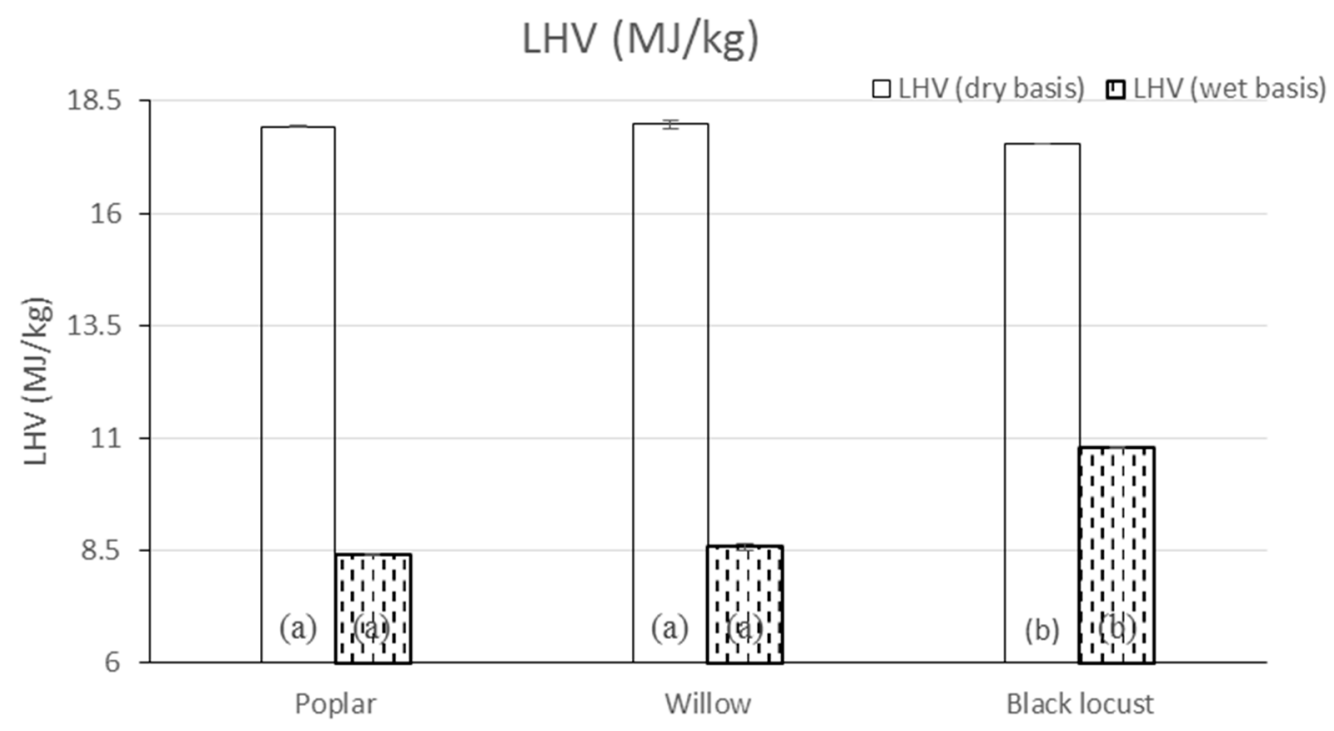

Figure 4. Mean lower heating values (LHV). Means values with a different letter are significantly different at $p<0.05$.

\section{Conclusions}

In this paper, the physical and thermo-chemical properties of three short rotation forestry crops (willow, black locust and poplar) were determined in order to select the most appropriate specie according to their combustion behavior in power plants. According to the results obtained, the following practical conclusions can be drawn:

- Based on the physical and thermochemical properties as well as on the production yield, willow seems to be the most suitable crop for use in combustion devices (low ash and high volatile content, high LHV on dry basis and very unlikely fouling problems).

- Despite the very low yield obtained for black locust (which was probably due to the unusual climatic conditions during the planting year), this specie could be cost-effective when constraints imposed by short storage periods (space availability and/or power production requirements) are limiting.

- The nitrogen and sulfur content in all the species suggests no problems related to $\mathrm{SO}_{X}$ and $\mathrm{NO}_{x}$ emissions.

- According to the fouling indexes determined, nor harmful corrosion caused by chlorine or fouling phenomena during combustion with any of the species are expected, those problems being minimized if willow is used.

Acknowledgments: The Ministry of Science and Innovation of Spain is gratefully acknowledged for its financial support through the LIGNOCROP Research Project (AEG09-059). The authors would like to thank the UCLM for financing Monedero within the UCLM's Own Research Plan.

Author Contributions: E.M. and J.J.H. conceived and designed the experimental testing strategy while R.C. carried out the experimental trials. E.M. wrote the manuscript and J.J.H. contributed for the analysis and interpretation of the results.

Conflicts of Interest: The authors declare no conflict of interest. The founding sponsor participated in the design of the study as well as in the data collection, and it agrees with the publication of the data

\section{References}

1. Perlack, R.D.; Wright, L.L.; Huston, M.A.; Schramm, W.E. Biomass Fuel from Woody Crops for Electric Power Generation; Biofuel Feedstock Development Program Energy Division Environmental Sciences Division, Oal Ridge National Laboratory: Oak Ridge, TN, USA, 1995. 
2. Manzone, M.; Bergante, S.; Facciotto, G. Energy and economic evaluation of a poplar plantation for woodchips production in Italy. Biomass Bioenergy 2014, 60, 164-170. [CrossRef]

3. Ericsson, K.; Rosenqvist, H.; Ganko, E.; Pisarek, M.; Nilsson, L. An agro-economic analysis of willow cultivation in Poland. Biomass Bioenergy 2006, 30, 16-27. [CrossRef]

4. Morogues, F.D.; Berthelot, A.; Merlun, F. Thoughts on the profitability of short and very short rotation coppice cycles with eucalyptus and poplar. Rev. For. Fr. 2011, 63, 705-721.

5. Manzone, M.; Bergane, S.; Facciotto, G. Energetic and economic sustainability of woodchips production by black locust (Robinia pseudoacacia L.) plantations in Italy. Fuel 2015, 140, 555-560. [CrossRef]

6. Dimitriou, I.; Mola-Yudego, B. Poplar and willow plantations on agricultural land in Sweden: Area, yield, groundwater quality and soil organic carbon. For. Ecol. Manag. 2017, 383, 99-107. [CrossRef]

7. Rösch, C.; Skarka, J.; Raab, K.; Stelzer, V. Energy production from grassland-Assessing the sustainability of different process chain under German conditions. Biomass Bioenergy 2009, 33, 689-700. [CrossRef]

8. Robbins, M.P.; Evans, G.; Valentine, J.; Donninson, I.S.; Allison, G.C. New opportunities for the exploitation of energy crops by thermochemical conversion in Northern Europe and the UK. Prog. Energy Combust. Sci. 2012, 38, 138-155. [CrossRef]

9. Sixto, H.; Hernández, M.J.; Barrio, M.; Carrasco, J.; Cañellas, I. Plantaciones del género Populus para la producción de biomasa con fines energéticos. Investig. Agrar. Sist. Recur. For. 2007, 16, 277-294. (In Spainish) [CrossRef]

10. Kuzovkina, Y.; Weith, M.; Abalos, M.; Charles, J.; Hurst, S.; Mcivor, I.; Karp, A.; Trybush, S.; Labrecque, M.; Teodorescu, T. Salix: Botany and global horticulture. Hortic. Rev. 2008, 34, 447-489.

11. Demirbas, A. Combustion characteristics of different biomass fuels. Prog. Energy Combust. Sci. 2004, 30, 219-230. [CrossRef]

12. McKendry, P. Energy production from biomass (part 1): Overview of biomass. Bioresour. Technol. 2002, 83, 37-46. [CrossRef]

13. EN 15103 Solid Biofuels. Determination of Bulk Density; Standard Number: BS EN 15103:2009; BSI: Brussels, Belgium, 2009.

14. Paris, P.; Pisanelli, A.; Sabatti, M.; Mareschi, L.; Cannata, F.; Scarascia-Mugnozza, G. Short Rotation Forestry in Italy. In Proceedings of the II Sino-Italian Workshop on Agroforestry, Beijing, China, 23-25 November 2005; p. 9.

15. Di Nasso, N.N.O.; Guidi, W.; Ragaglini, G.; Tozzini, C.; Bonari, E. Biomass production and energy balance of a 12-year-old short-rotation coppice poplar stand under different cutting cycles. GCB Bioenergy 2010, 2, 89-97. [CrossRef]

16. Carmona, R.; Nuñez, T.; Alonso, M.F. Biomass yield and quality of an energy dedicated crop of poplar (Populus spp.) clones in the Mediterranean zone of Chile. Biomass Bioenergy 2015, 74, 96-1022. [CrossRef]

17. Sixto, H.; Cañellas, I.; Arendonk, J.; Ciria, P.; Camps, F.; Sánchez, M.; Sánchez-González, M. Growth potential of different species and genotypes for biomass production in short rotation in Mediterranean environments. For. Ecol. Manag. 2015, 354, 291-299. [CrossRef]

18. Nordin, A. Chemical elemental characteristics of biomass fuels. Biomass Bioenergy 1994, 6, 339-347. [CrossRef]

19. Liao, C.; Wu, C.; Yan, Y.; Huang, H. Chemical elemental characteristics of biomass fuels in China. Biomass Bioenergy 2004, 27, 119-130.

20. Tao, G.; Lestander, T.; Geladi, P.; Xiong, S. Biomass properties in association with plant species and assortments I: A synthesis based on literature data of energy properties. Renew. Sustain. Energy Rev. 2012, 16, 3481-3506. [CrossRef]

21. Monedero, E.; Hernandez, J.J.; Cañellas, I.; Otero, J.M.; Sixto, H. Thermochemical and physical evaluation of poplar genotypes as short rotation forestry crops for energy use. Energy Convers. Manag. 2016, 129, 131-139. [CrossRef]

22. Picchio, R.; Spina, R.; Sirna, A.; Monaco, L.A.; Civitarese, V.; Giudice, D.A.; Suardi, A.; Pari, L. Characterization of Woodchips for Energy from forestry and agroforestry production. Energies 2005, 5, 3803-3816. [CrossRef]

23. Verani, S.; Sperandio, G.; Picchio, R.; Marchi, E.; Costa, C. Sustainability assessment of a self-consumption wood-energy chain on small scale for heat generation in central Italy. Energies 2015, 8, 5182-5197. [CrossRef]

24. Tharakan, P.J.; Volk, T.A.; Abrahamson, L.P.; White, E.H. Energy feedstock characteristics of willow and hybrid poplar clones at harvested age. Biomass Bioenergy 2003, 25, 571-580. [CrossRef] 
25. Grunewald, H.; Böhm, C.; Quinkenstein, A.; Grundmann, P.; Eberts, J.; Wühlisch von, G. Robinia pseudoacacia L.: A lesser known tree species for biomass production. Bioenergy Res. 2009, 2, 123-133. [CrossRef]

26. Hanover, J.W.; Mebrahtu, T. Robinia pseudoacacia: Temperate Legume Tree with Worldwide Potential; NFT Highlights; NFTA: Buffalo, NY, USA, 1991.

27. Peters, K.; Bilke, G.; Strohbach, B. Ertragsleistung sechsjähriger Robinien (Robinia pseudoacacia) auf vier ehemaligen Ackerstandorten unterschiedlicher Bodengüte in Brandenburg. Arch. Forstwes. Landsch. 2007, 1, 26-28. (In German)

28. Rédei, K. Black Locust (Robinia pseudoacacia L.) Growing in Hungary; Publications of the Hungarian Forest Research Institute: Budapest, Ungarn, 1998.

29. Werner, A.; Vetter, A.; Reinhold, G. Leitlinie zur Effizienten und Umweltverträglichen Erzeugung Von Energieholz; Thüringer Landesanstalt für Landwirtschaft: Jena, Germany, 2006. (In German)

30. EN 14780 Solid Biofuels. Sample Preparation; Standard Number BS EN 14780:2011; BSI: Brussels, Belgium, 2017.

31. Tariq, A.S.; Purvis, M.R.I. $\mathrm{NO}_{x}$ emissions and thermal efficiencies of small scale biomass-fuelled combustion plant with reference to process industries in a developing country. Int. J. Energy Res. 1996, 20, 41-55. [CrossRef]

32. Erber, G.; Kanzian, C.; Stampfer, K. Predicting moisture content in a pine logwood pile for energy purposes. Silva Fenn. 2012, 46, 555-567. [CrossRef]

33. Manzone, M. Energy and moisture losses during poplar and black locust logwood storage. Fuel Proc. Technol. 2015, 138, 194-201. [CrossRef]

34. Eisenbies, M.H.; Timothy, A.; Patel, A. Changes in feedstock quality in willow chip piles created in winter from a commercial scale harvest. Biomass Bioenergy 2016, 86, 180-190. [CrossRef]

35. Chirone, R.; Salatino, P.; Sacala, F. The relevance of attrition to the fate of ashes during fluidized bed combustion of a biomass. Proc. Combust. Inst. 2000, 28, 2279-2286. [CrossRef]

36. Meszaros, E. Comparative study of the thermal behavior of wood and bark of young shoots obtained from an energy plantation. J. Anal. Appl. Pyrolysis 2004, 72, 317-328. [CrossRef]

37. Khalil, R.A.; Mészáros, E.; Grønli, M.G.; Várhegyi, G. Thermal analysis of energy crops: Part I: The applicability of macro-thermobalance for biomass studies. J. Anal. Appl. Pyrolysis 2008, 81, 52-59. [CrossRef]

38. Fernández, M.J.; Borjabad, E.; Barro, R.; Losada, J.; Bados, R.; Ramos, R.; Carrasco, J.E. Estudio sobre sinterización de las cenizas de biomasas en la combustión; Informe Técnico PSE on Cultivos: Soria, Spain, 2008.

39. Obenberguer, I. Nutzung Fester Biomasse in Verbrennungsalagen unter Besondere Berïcksichtigung des Verhalens Aschebildender Elemente. Schriftenreihe "Thermische Biomassenutzung", Band 1; dbv-Verlag für die Technische Universität: Graz, Austria, 1997; ISBN 3-7041-0241-5. (In German)

40. Vassilev, S.V.; Baxter, D.; Andersen, L.; Vassileva, C.; Morgan, T. An overview of the organic and inorganic phase composition of biomass. Fuel 2012, 94, 1-33. [CrossRef]

41. Vassilev, S.V.; Baxter, D.; Andersen, L.; Vassileva, C. An overview of the chemical composition of biomass. Fuel 2010, 84, 911-933. [CrossRef]

42. Magasiner, N.; Kock, D.J. Design Criteria for Fibrous Fuel Fired Boilers. Energy World 1987, 150, 4-12.

43. Miles, P.; Miles, J.N.; Baxter, L.L.; Bryers, R.W.; Jenkins, B.M.; Oden, L.L. Alkali Deposits Found in Biomass Power Plants-A Preliminary Investigation of Their Extent and Nature Summary Report for Natural Renewable Energy Laboratory; SciTech Connect: Golden, CO, USA, 1995.

44. Klasnja, B.; Kopitovic, S.; Orlovic, S. Wood and bark of some poplar and willow clones as fuelwood. Biomass Bioenergy 2002, 23, 427-432. [CrossRef]

(c) 2017 by the authors. Licensee MDPI, Basel, Switzerland. This article is an open access article distributed under the terms and conditions of the Creative Commons Attribution (CC BY) license (http://creativecommons.org/licenses/by/4.0/). 